\title{
Clinical benefit of readministration of gefitinib for initial gefitinib-responders with non-small cell lung cancer
} Hiroshi Yokouchi1, 7 , Koichi Yamazaki*1,7, Ichiro Kinoshita ${ }^{2,7}$, Jun Konishi1, 7 ,

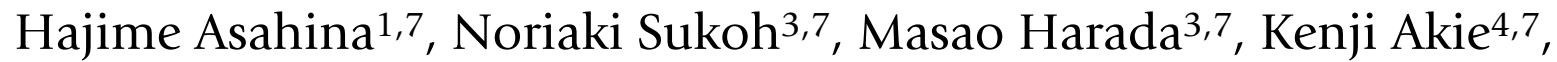
Shigeaki Ogura ${ }^{4,7}$, Takashi Ishida ${ }^{5,7}$, Mitsuru Munakata ${ }^{5,7}$, Hirotoshi DosakaAkita $^{2,7}$, Hiroshi Isobe ${ }^{3,6,7}$ and Masaharu Nishimura ${ }^{1,7}$

Address: ${ }^{1}$ First Department of Medicine, Hokkaido University School of Medicine, Sapporo, Japan, ${ }^{2}$ Department of Medical Oncology, Hokkaido University Graduate School of Medicine, Sapporo, Japan, ${ }^{3}$ Department of Respiratory Medicine, National Hospital Organization Hokkaido Cancer Center, Sapporo, Japan, ${ }^{4}$ Department of Respiratory Disease, Sapporo City General Hospital, Sapporo, Japan, ${ }^{5}$ Department of Pulmonary Medicine, Fukushima Medical University, Fukushima, Japan, ${ }^{6}$ Department of Medical Oncology, KKR Sapporo Medical Center, Sapporo, Japan and ${ }^{7}$ Hokkaido Lung Cancer Clinical Research Group, Sapporo, Japan

Email: Hiroshi Yokouchi - yokouchi@med.hokudai.ac.jp; Koichi Yamazaki* - kyamazak@med.hokudai.ac.jp; Ichiro Kinoshita - kinoshii@med.hokudai.ac.jp; Jun Konishi - biyonbiyon99@yahoo.co.jp; Hajime Asahina - hajime.asahina@nifty.ne.jp; Noriaki Sukoh - sukou@sap-cc.go.jp; Masao Harada - mharada@sap-cc.go.jp; Kenji Akie - kenji.akie@doc.city.sapporo.jp; Shigeaki Ogura - shigeaki.ogura@doc.city.sapporo.jp; Takashi Ishida - taku.ishida@nifty.ne.jp; Mitsuru Munakata - munakata@fmu.ac.jp; Hirotoshi Dosaka-Akita - hdakita@med.hokudai.ac.jp; Hiroshi Isobe - h-isobe@kkr-smc.com; Masaharu Nishimura - manishi@med.hokudai.ac.jp

* Corresponding author

Published: 20 March 2007

BMC Cancer 2007, 7:5I doi:I0.1 I86/I47|-2407-7-5I
Received: 19 September 2006

Accepted: 20 March 2007

This article is available from: http://www.biomedcentral.com/147I-2407/7/5I

(c) 2007 Yokouchi et al; licensee BioMed Central Ltd.

This is an Open Access article distributed under the terms of the Creative Commons Attribution License (http://creativecommons.org/licenses/by/2.0), which permits unrestricted use, distribution, and reproduction in any medium, provided the original work is properly cited.

\begin{abstract}
Background: Gefitinib, an oral agent of epidermal growth factor receptor tyrosine kinase inhibitor, has a certain efficacy against non-small cell lung cancer (NSCLC). Several predictive factors of gefitinib sensitivity have been well described. However, few studies have investigated the clinical features of gefitinib-responders. In the present study, we analyzed the response and disease progression of primary and metastatic lesions to gefitinib in responders and the results of gefitinib readministration following temporary cessation of gefitinib upon progression of initial gefitinib treatment and other treatments.
\end{abstract}

Method: We retrospectively evaluated the clinical courses of 27 NSCLC patients who received gefitinib and achieved either a complete or partial response.

Results: The best-response rate and disease-control rate against the initial chemotherapy for the gefitinibresponders were $27.3 \%$ and $77.3 \%$, respectively. Favorable efficacy was observed in the primary lesion and metastases to the lung, liver and brain, while there was no obvious effect on bone metastasis. The primary lesion and intrapulmonary metastasis were the sites of major recurrence. Median progression-free survival was 13.8 months, median duration of gefitinib treatment was 17.0 months and median overall survival was 29.2 months. Some of the patients who experienced disease progression after responding to gefitinib were again sensitive to readministration of gefitinib following temporary cessation of gefitinib and other treatments.

Conclusion: Patients may still be expected to have prolonged survival if they once responded to gefitinib and then underwent various subsequent treatments followed by readministration of gefitinib. These findings might provide valuable information for the management of gefitinib-responders. 


\section{Background}

Although chemotherapy improves survival in advanced NSCLC patients, it appears to have reached a therapeutic plateau and novel approaches are urgently required. Under these circumstances, inhibition of the epidermal growth factor receptor (EGFR) tyrosine kinase has emerged as a therapeutic option in patients with NSCLC. Gefitinib, an oral EGFR tyrosine kinase inhibitor (EGFRTKI), is a leading agent in this class of novel therapeutic agents. It is now clear that there are limited subgroups of patients who derive particular benefit from this treatment. Two major phase II trials $[1,2]$, large expanded access programs across the world [3-6] and other studies $[7,8]$ have demonstrated a higher objective-response rate and prolonged survival in women, never-smokers, patients with adenocarcinoma, and East-Asian patients. Moreover, a prospective trial using gefitinib as a first-line therapy for advanced lung adenocarcinoma patients with never smoking status was conducted in Korea, with excellent efficacy confirmed [9].

A molecular approach linked to gefitinib sensitivity has also been attempted. Mutations $[10,11]$ and amplification [12] of the EGFR gene, and other molecules such as phosphorylated Akt [13] and ErbB-3 expression [14] have been well described as markers of a better outcome in patients treated with gefitinib. Furthermore, correlation between some of these predictors and clinical benefit has been retrospectively confirmed in many reports [15-22]. However, few reports have examined the clinical courses of gefitinib-responders.

In the present study, we investigated the clinical courses of gefitinib responders, by analyzing the response and disease progression of primary and metastatic lesions by gefitinib in responders and the results of gefitinib readministration (resumption of, or rechallenge with, gefitinib) following temporary cessation of gefitinib upon progression of initial gefitinib treatment and other treatments. Our results provide additional information regarding gefitinib use for advanced NSCLC patients.

\section{Methods}

\section{Patients and treatment}

From August 2002 to March 2004, a total of 122 patients with histologically or cytologically confirmed advanced NSCLC received $250 \mathrm{mg} /$ day gefitinib orally at our institutes (Hokkaido University Hospital, National Hospital Organization Hokkaido Cancer Center, Sapporo City General Hospital and Fukushima Medical University Hospital, Japan). We reviewed their medical records and imaging findings. The histopathological classification was based on WHO criteria [23]. Treatment was primarily continued until disease progression (PD), death, intolerable side effects determined by physicians or withdrawal of consent. No other systemic chemotherapy was performed during gefitinib treatment in any of the patients, although some received radiotherapy for metastasis or pleurodesis after temporary cessation of gefitinib, followed by resumption of gefitinib.

The clinical features of the 27 (22.1\%) patients who were defined as having a complete (CR) or partial response (PR) to gefitinib were retrospectively analyzed. Objective tumor response was determined in accordance with the Response Evaluation Criteria in Solid Tumors Group (RECIST) guidelines [24]. Disease control was categorized as CR, PR, or stable disease (SD). CR and PR required a sustained response for 4 weeks or longer, while this was 8 weeks or longer for SD. Most patients who started gefitinib were admitted to hospital and underwent weekly chest X-rays for the initial 4 weeks, and then underwent monthly chest X-rays and computed tomography (CT) including target lesions with or without brain magnetic resonance imaging (MRI) or bone scintigraphy every three months at the outpatient clinic. Objective tumor response was confirmed by CT, MRI, and bone scintigraphy. Progression-free survival (PFS) and overall survival (OS) were calculated from the date of initiation of gefitinib. Patients who were not deceased were censored at the date of last contact with our institutions. The duration of gefitinib treatment was calculated from the date of initiation of gefitinib to the date of withdrawal of gefitinib. In the present study, readministration of gefitinib was divided into resumption and rechallenge of gefitinib. "Resumption of" or "resuming" gefitinib indicates the restarting of gefitinib administration within 4 weeks after cessation of gefitinib and other treatments such as radiotherapy for metastasis or pleurodesis, but not chemotherapy. "Rechallenge" with gefitinib indicates the restarting of gefitinib after cessation of gefitinib and cessation of several cycles of other chemotherapy.

\section{Statistical analysis}

PFS and OS probability estimates were based on the Kaplan-Meier method. Confidence intervals were calculated at the $95 \%$ level (95\% CI). Dr. SPSS software (SPSS, Inc., Chicago, IL) was used for the analyses.

\section{Results}

Differential response and disease progression of primary and metastatic lesions by gefitinib

Of the entire cohort of 122 patients who were treated with gefitinib, $27(22.1 \%)$ were defined as PR. No patient achieved CR. Female patients, patients with never-smoked status and patients with adenocarcinoma showed a higher response as described previously [7].

Table 1 shows the response of primary and metastatic lesions to gefitinib in the responders. The primary tumor 
Table I: The response of primary and metastatic lesions to gefitinib in responders

\begin{tabular}{lcccc}
\hline Site & No. of patients & No. improved & No. of patients with target lesion & Average tumor shrinkage of target lesion (\%, mean \pm SD) \\
\hline $\begin{array}{l}\text { Primary lesion } \\
\text { Metastatic lesion }\end{array}$ & 27 & 27 & 21 & $46.5 \pm 19.4$ \\
$\quad$ Intrapulmonary & 12 & 12 & 9 & $73.8 \pm 30.6$ \\
Liver & 4 & 4 & 3 & $47.3 \pm 21.6$ \\
CNS & 4 & 4 & 2 & $65.0 \pm 21.2$ \\
Bone & 8 & 0 & & \\
Pleural effusion & 6 & 5 & & \\
Others & 2 & 2 & & \\
\hline
\end{tabular}

CNS, central nervous system

shrunk by $46.5 \pm 19.4 \%$ (mean \pm SD) in the 21 assessable gefitinib-responders. At the start of gefitinib administration, 12 patients $(44.4 \%)$ had intrapulmonary metastases, all of which regressed by gefitinib. The intrapulmonary metastases in 9 patients were assessed as target lesions and the percentage of shrinkage of these target lesions was $73.8 \pm 30.6 \%$. The response of liver and brain metastases, and pleural effusion, to gefitinib was also favorable. Bone metastasis was initially detected in 8 patients $(29.6 \%)$, and remained unchanged after gefitinib treatment, as confirmed by bone scintigraphy.

The sites of initial disease progression after response to gefitinib among the 27 responders are summarized in Table 2 . The initial recurrent sites were seen in the primary lesion in 8 (29.6\%) patients, intrapulmonary lesion in 8 $(29.6 \%)$, bone in $5(18.5 \%)$, central nervous system (CNS) in $3(11.1 \%)$, and pleural effusion in $6(22.2 \%)$.

\section{Gefitinib readministration following temporary cessation of gefitinib upon progression of initial gefitinib treatment and other treatments}

Table 3 shows the clinical courses of initial gefitinibresponders upon progression of initial gefitinib treatment. At the time of writing, 3 responders are maintaining $P R$ and remain on gefitinib. Two patients have ceased gefitinib during PR at their request, and the other 22 patients have developed PD. Of these 22, 4 continued to receive gefitinib at their request and regardless of $\mathrm{PD}$ and the availability of other treatments.

Another 4 of the 22 patients with PD underwent various treatments, except chemotherapy, for new or progressed lesions and then resumed gefitinib (Table 4). Patient 1 developed a new bone metastasis and increment of malignant pleural effusion regardless of regression of intrapulmonary tumors. This patient received irradiation for the bone metastasis, pleurodesis, and then resumed gefitinib. Patient 2 developed a brain metastasis and thus underwent whole brain irradiation, after which gefitinib was resumed because intrathoracic disease remained well controlled. Patient 3 developed a new bone metastasis regardless of good control of intrathoracic disease. The patient underwent irradiation for the bone metastasis and then resumed gefitinib. Patient 4 who had well-controlled intrapulmonary tumors, underwent irradiation for brain and bone metastases, pleurodesis, and then gefitinib again. Judging from the dates of resumption, all 4 patients were confirmed as SD. The range of time to re-progression was from 2.9 months to more than 19.1 months.

Nine of the 22 patients underwent systemic chemotherapy when reaching PD. Of these 9 patients, 6 chose to receive gefitinib again after chemotherapy (Table 5). Judging from the point of rechallenge of gefitinib, one patient achieved PR, three patients SD, one patient PD and one

Table 2: The sites of initial disease progression after response to gefitinib

\begin{tabular}{lcc}
\hline Site & No. of patients & $\%$ \\
\hline Primary lesion & 8 & 29.6 \\
Metastatic lesion & & 29.6 \\
$\quad$ Intrapulmonary & 8 & 22.2 \\
Pleural effusion & 6 & 18.5 \\
Bone & 5 & 11.1 \\
CNS & 3 & 0 \\
Others & 0 & 0 \\
\hline
\end{tabular}

CNS, central nervous system 
Table 3: Clinical course of gefitinib-responders

\begin{tabular}{lc}
\hline Clinical course & No. of patient \\
\hline Maintain PR and still continue & 3 \\
Cessation by patient's will during PR & 2 \\
Disease progression (PD) & 22 \\
$\quad$ Insistence to continue & 4 \\
Resumption & 4 \\
Rechallenge & 6 \\
Cessation of gefitinib by PD and no therapy & 8 \\
\hline
\end{tabular}

patient was not evaluative (NE). The range of time to reprogression from gefitinib rechallenge was 0.6 months to 7.8 months.

In the present cohort of 122 patients, the median follow up of the 27 initial gefitinib-responders was 23.7 months, the median PFS, 13.8 months $(95 \% \mathrm{CI}=11.4$ to 16.2 months); and the median OS, 29.2 months (95\% CI = 22.1 to 36.4 months) (Figure 1). The estimated 1-year survival rate was $85.2 \%$. Because many patients continued to take gefitinib even after disease progression, the median duration of gefitinib treatment was 17.0 months (95\% CI $=13.2$ to 20.8 months).

\section{Discussion}

In the present retrospective study, we analyzed the clinical courses of gefitinib-responders during and after failure of the treatment by analyzing the response and disease progression of primary and metastatic lesions by gefitinib in responders, and the results of gefitinib readministration following temporary cessation of gefitinib upon progression of initial gefitinib treatment and other treatments.

The median PFS and median duration of gefitinib treatment were 13.8 months and 17.0 months, respectively, revealing an approximately 3.2 month difference between PFS and the time to cessation of gefitinib. In some patients, other treatments against pleural effusion, or against bone or brain metastasis, were successful, while intrapulmonary or intrathoracic diseases were stable. Physicians and patients decided together whether to continue, resume or rechallenge with gefitinib.
One of the most striking results in the present study was that PR or SD was achieved upon gefitinib rechallenge following systemic chemotherapy in 4 of 6 patients who responded to the first administration of gefitinib. There has been only one similar case reported [25]. This phenomenon is difficult to explain. One possibility is that the passage of time or cytotoxic chemotherapy may have reduced the number of clones containing modified genes and proteins that confer resistance to gefitinib. The mechanism of this phenomenon may involve a second pointmutation, resulting in a threonine-to-methionine amino acid change at position 790 of EGFR (T790M) [26,27], mutation in the KRAS protein [28], or upregulation of epithelial membrane protein-1 [29]. It would be of great benefit to perform comparative molecular analyses of tissue specimens before and after gefitinib treatment in responders.

In the present study, the OS was 29.2 months, which was much longer than that in three previous retrospective reports [19,30,31] focusing on patients who had responded to gefitinib (16 to 20.3 months). Differences in gender, never-smoked status, presence of adenocarcinoma, and ethnicity may be responsible in part for the altered outcome between the responders in the present study and those in the three previous studies. Moreover, the strategy of resumption or rechallenge of gefitinib for gefitinib-responders may also have played a role in the longer survival observed in the present study.

Hotta et al. [32] noted the importance of achieving SD with gefitinib, based on their finding that the OS in

Table 4: Clinical course of the gefitinib-responders who achieved PD, underwent various treatments except for chemotherapy, and resumed gefitinib

\begin{tabular}{clcc}
\hline No. & Treatment after gefitinib failure & Response after gefitinib resumption & Time to re-progression (month) \\
\hline I & RT to bone mets, Pleurodesis, & SD & 2.9 \\
2 & RT to brain mets, & SD & 8.9 \\
3 & RT to bone mets, & SD & $19.1+$ \\
4 & RT to bone and brain mets, Pleurodesis, & SD & 6.5
\end{tabular}

\footnotetext{
"Resumption" of gefitinib indicates restarting gefitinib within 4 weeks after temporary cessation of gefitinib. RT, radiotherapy; mets, metastasis; Time to re-progression, time to progression from the date of resuming gefitinib; +, still continuing the response at the last date of follow-up
} 
Table 5: Clinical course of the gefitinib-responders who achieved PD, underwent chemotherapy, and rechallenged with gefitinib

\begin{tabular}{ccccc}
\hline No. & $\begin{array}{c}\text { Chemotherapy regimen after failure of } \\
\text { gefitinib }\end{array}$ & $\begin{array}{c}\text { Best response of the } \\
\text { chemotherapy }\end{array}$ & $\begin{array}{c}\text { Response of gefitinib } \\
\text { rechallenge }\end{array}$ & $\begin{array}{c}\text { Time to re-progression } \\
\text { (month) }\end{array}$ \\
\hline 5 & GEM+VNR & PR & PR & 6.2 \\
6 & GEM+VNR & PD & SD & 7.8 \\
7 & GEM+DTX & SD & PD & 0.6 \\
8 & CBDCA+CPT-II $\rightarrow$ AMR $\rightarrow$ S-I & SD & SD & $1.9+$ \\
9 & DTX & SD & SD & $4.3+$ \\
10 & DTX & SD & NE & $0.9+$ \\
\hline
\end{tabular}

"Rechallenge" of gefitinib indicates restarting gefitinib after cessation of gefitinib followed by other chemotherapy. GEM, gemcitabine; VNR, vinorelbine; DTX, docetaxel; CBDCA, carboplatin; CPT-I I, irinotecan; AMR, amrubicin; Time to re-progression, time to progression from the date of rechallenging gefitinib; + , still continuing the response at the last date of follow-up

patients who obtained SD was significantly longer than that in patients with PD. It is of interest whether resumption of, or rechallenge with, gefitinib after treatment of a recurrence site contributes to the patients' survival by achieving PR or maintaining SD for a long time. With regard to rechallenge, we are performing a prospective phase II trial of gefitinib rechallenge to gefitinib-responders following chemotherapy.

Our analysis of the initial sites of disease recurrence in patients who initially responded to gefitinib revealed a relatively higher prevalence of intrapulmonary and primary lesion metastasis at the initial disease recurrence site than at other organs. Furthermore, although a previous report [30] noted that CNS metastasis was a frequently observed disease recurrence site $(33 \%)$ in gefitinibresponders, only 3 patients $(11.1 \%)$ developed CNS metastasis in the present study. There were more patients who had pleural effusion or bone metastasis at the initiation of gefitinib in our cohort.

\section{Conclusion}

Patients may still be reasonably expected to have prolonged survival if they once responded to gefitinib and then underwent various subsequent treatments followed by failure of a second round of gefitinib. These findings provide valuable information for the management of gefitinib-responders. Further research and clinical trials

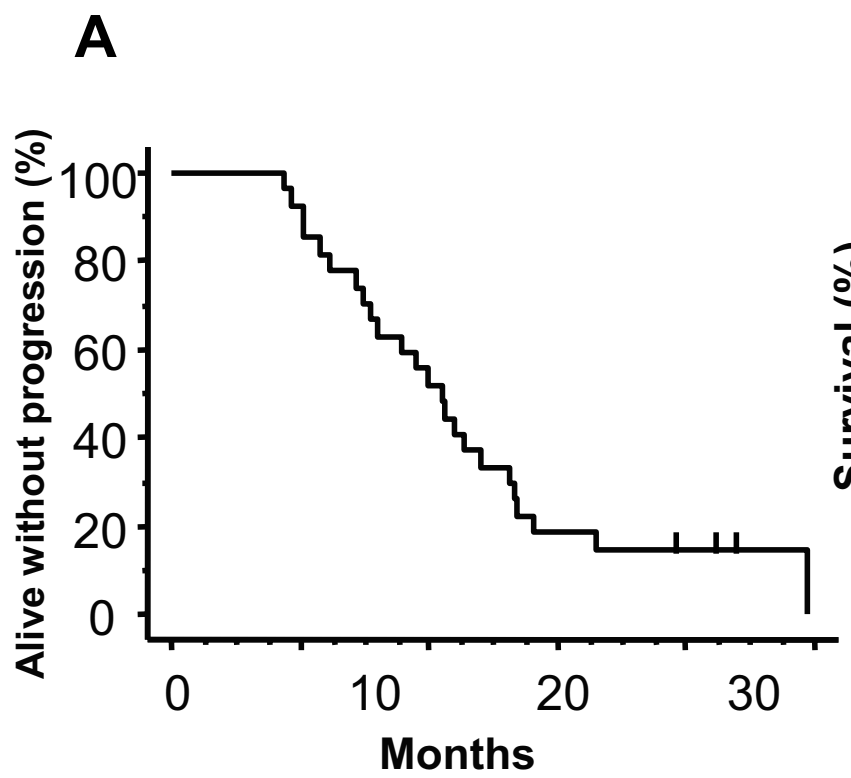

B

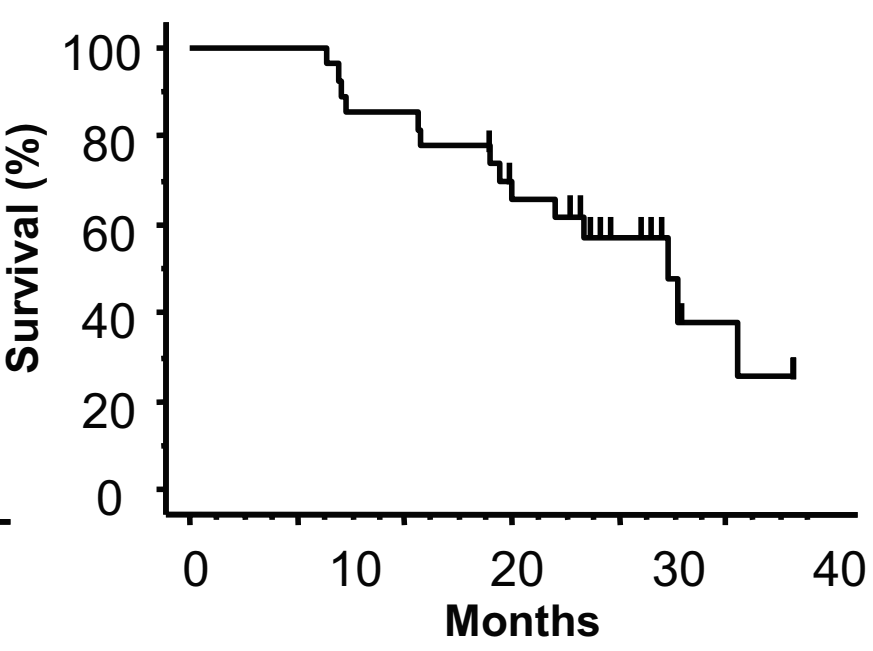

Figure I

Kaplan-Meier estimates of progression-free survival (PFS, A) and overall survival (OS, B) for gefitinib-responders. Median PFS was 13.8 months $(95 \% \mathrm{Cl}=\mathrm{I} \mathrm{I} .4$ to $\mathrm{I} 6.2$ months) and median OS was 29.2 months $(95 \% \mathrm{Cl}=22 . \mathrm{I}$ to 36.4 months). Bars indicate censored cases. 
based on the present findings will be needed to develop more effective treatment strategies and to improve the clinical practice of appropriate gefitinib administration in advanced NSCLC patients.

\section{Competing interests}

The author(s) declare that they have no competing interests.

\section{Authors' contributions}

HY reviewed the medical records and imaging findings, drafted the manuscript and coordinated the submission. $\mathrm{KY}$ designed the analysis and critically revised the manuscript. IK, HDA, and MN participated in reviewing the manuscript. JK, AH, NS, MH, KA, SO, TI, MM, and HI followed the patients and participated in the acquisition of data. All authors read and approved the final manuscript.

\section{Acknowledgements}

The research reported in this manuscript has been performed with the approval of the Institutional Review Board and Ethics Committee of each institution and is in compliance with the Helsinki Declaration.

\section{References}

I. Fukuoka M, Yano S, Giaccone G, Tamura T, Nakagawa K, Douillard JY, Nishiwaki Y, Vansteenkiste J, Kudoh S, Rischin D, Eek R, Horai T, Noda K, Takata I, Smit E, Averbuch S, Macleod A, Feyereislova A, Dong RP, Baselga J: Multi-institutional randomized phase II trial of gefitinib for previously treated patients with advanced non-small-cell lung cancer. J Clin Oncol 2003, 21 :2237-46.

2. Kris MG, Natale RB, Herbst RS, Lynch TJ, Prager D, Belani CP, Schiller $J \mathrm{H}$, Kelly K, Spiridonidis H, Sandler A, Albain KS, Cella D, Wolf MK, Averbuch SD, Ochs JJ, Kay AC: Efficacy of gefitinib, an inhibitor of the epidermal growth factor receptor tyrosine kinase, in symptomatic patients with non-small cell lung cancer. JAMA 2003, 290:2149-58.

3. Ochs J, Grous J, Warner KL: Final survival and safety results for 2I,064 non-small cell lung cancer (NSCLC) patients who received compassionate use gefitinib (Iressa ${ }^{\circledR}$ ) in a United States expanded access program (EAP). Proc Am Soc Clin Oncol 2004, 23:628.

4. Janne PA, Gurubhagavatula S, Yeap BY, Lucca J, Ostler P, Skarin AT, Fidias $P$, Lynch TJ, Johnson BE: Outcomes of patients with advanced non-small cell lung cancer treated with gefitinib (ZD 'Iressa') on and expanded access study. Lung Cancer 1839, 44:22I-30.

5. Santoro A, Cavina R, Latteri F, Zucali PA, Ginanni V, Campagnoli E, Ferrari B, Morenghi E, Pedicini V, Roncalli M, Alloisio M, Ravasi G, Soto Parra HJ: Activity of a specific inhibitor, gefitinib (Iressa, ZD I 839), of epidermal growth factor receptor in refractory non-small-cell lung cancer. Ann Oncol 2004, I 5:33-7.

6. Park J, Park BB, Kim JY, Lee SH, Lee SI, Kim HY, Park SH, Lee KE, Park JO, Kim K, Jung CW, Park YS, Im YH, Kang WK, Lee MH, Park K: Gefitinib (ZDI839) monotherapy as a salvage regimen for previously treated advanced non-small cell lung cancer. Clin Cancer Res 2004, 10:4383-8.

7. Konishi J, Yamazaki K, Kinoshita I, Isobe H, Ogura S, Sekine S, Ishida T, Takashima R, Nakadate M, Nishikawa S, Hattori T, Asahina H, Imura M, Kikuchi E, Kikuchi J, Shinagawa N, Yokouchi H, Munakata M, Dosaka-Akita H, Nishimura M: Analysis of the response and toxicity to gefitinib of non-small cell lung cancer. Anticancer Res 2005, 25:435-42.

8. Simon GR, Ruckdeschel JC, Williams C, Cantor A, Chiappori A, Rocha Lima CM, Antonia S, Haura E, Wagner H, Robinson L, Sommers E, Alberts M, Bepler G: Gefitinib (ZD | 839) in previously treated advanced non-small-cell lung cancer: experience from a single institution. Cancer control 2003, 10:388-95.
9. Lee DH, Han JY, Lee HG, Lee J], Lee EK, Kim HY, Kim HK, Hong EK, Lee JS: Gefitinib as a first-line therapy of advanced or metastatic adenocarcinoma of the lung in never-smokers. Clin Cancer Res 2005, I I:3032-7.

10. Lynch TJ, Bell DW, Sordella R, Gurubhagavatula S, Okimoto RA, Brannigan BW, Harris PL, Haserlat SM, Supko JG, Haluska FG, Louis DN, Christiani DC, Settleman J, Haber DA: Activating mutations in the epidermal growth factor receptor underlying responsiveness of non-small-cell lung cancer to gefitinib. NEngl J Med 2004, 350:2129-39.

II. Paez JG, Janne PA, Lee JC, Tracy S, Greulich H, Gabriel S, Herman P, Kave FJ, Lindeman N, Boggon Tj, Naoki K, Sasaki H, Fujii Y, Eck MJ, Sellers WR, Johnson BE, Meyerson M: EGFR mutations in lung cancer; correlation with clinical response to gefitinib therapy. Science 2004, 304: | 497-500.

12. Cappuzzo F, Hirsch FR, Rossi E, Bartolini S, Ceresoli GL, Bemis L, Haney J, Witta S, Danenberg K, Domenichini I, Ludovini V, Magrini E, Gregorc V, Doglioni C, Sidoni A, Tonato M, Franklin WA, Crino L, Bunn PA, Varella-Garcia M: Epidermal growth factor receptor gene and protein and gefitinib sensitivity in non-small-cell lung cancer. J Natl Cancer Inst 2005, 97:643-55.

13. Cappuzzo F, Magrini E, Ceresoli GL, Bartolini S, Rossi E, Ludovini V, Gregorc V, Ligorio C, Cancellieri A, Damiani S, Spreafico A, Paties CT, Lombardo L, calandri C, Bellezza G, Tonato M, Crino L: Akt phosphorylation and gefitinib efficacy in patients with advanced non-small-cell lung cancer. J Natl Cancer Inst 2004, I5: I| $33-4 \mid$

14. Engelman JA, Janne PA, Mermel C, Pearlberg J, Mukohara T, Fleet C, Cichowski K, Johnson BE, Cantley LC: ErbB-3 mediates phosphoinositide 3-kinase activity in gefitnib-sensitive non-small cell lung cancer cell lines. Proc Natl Acad Sci USA 2005, 102:3788-93.

15. Mitsudomi T, Kosaka T, Endoh H, Horio Y, hida T, Mori S, Hatooka S, Shinoda M, Takahashi T, Yatabe Y: Mutations of the epidermal growth factor receptor gene predict prolonged survival after gefitinib treatment in patients with non-small-cell lung cancer with postoperative recurrence. J Clin Oncol 2005, 23:25I3-20.

16. Han SW, Kim TY, Hwang PG, Jeong S, Kim J, choi IS, Oh DY, Kim JH, Kim DW, Chung DH, Im SA, Kim YT, Lee JS, Heo DS, Bang YJ, Kim NK: Predictive and prognostic impact of epidermal growth factor receptor mutation on non-small-cell lung cancer patients treated with gefitinib. I Clin Oncol 2005, 23:2493-50I.

17. Hirsch FR, Garcia MV, McCoy J, West H, Xavier AC, Gumerlock P, Bunn PA, Franklin WA, Crowley J, Gandara DR: Increased epidermal growth factor receptor gene copy number detected by fluorescence in situ hybridization associates with increased sensitivity to gefitinib in patients with bronchioloalveolar carcinoma subtypes: a southwest oncology group study. J Clin Oncol 2005, 23:6838-45.

18. Tokumo M, Toyooka S, Kiura K, Shigematsu H, Tomii K, Aoe M, Ichimura K, Tsuda T, Yano M, Tsukuda K, Tabata M, Ueoka H, Tanimoto $M$, Date $H$, Gazdar AF, Shimizu N: The relationship between epidermal growth factor receptor mutations and clinicopathologic features in non-small cell lung cancers. Clin Cancer Res 2005, I I: I I67-73.

19. Kim KS, Jeong JY, Kim YC, Na KJ, Kim YH, Ahn SJ, Baek SM, Park CS, Park CM, Kim YI, Lim SC, Park KO: Predictors of the response to gefitinib in refractory non-small cell lung cancer. Clin Cancer Res 2005, I I:2244-5I.

20. Chou TY, Chiu CH, Li LH, Hsiao CY, Tzen CY, Chang KT, Chen YM, Perng RP, Tsai SF, Tsai CM: Mutations in the tyrosine kinase domain of epidermal growth factor receptor is a predictive factor for gefitinib treatment in patients with non-small cell lung cancer. Clin Cancer Res 2005, I I:3750-7.

21. Takano T, Ohe Y, Sakamoto H, Tsuta K, Matsuno Y, Tateishi U, Yamamoto S, Nokihara H, Yamamoto N, Sekine I, Kunitoh H, Shibata T, Sakiyama T, Yoshida T, Tamura T: Epidermal growth factor receptor gene mutations and increased copy number predict gefitinib sensitivity in patients with recurrent non-smallcell lung cancer. I Clin Oncol 2005, 23:6829-37.

22. Rielly GJ, Pao W, Pham D, Li AR, Rizvi N, Venkatraman ES, Zakowski MF, Kris MG, Ladanyi M, Miller VA: Clinical course of patients with non-small cell lung cancer and epidermal growth factor receptor exon 19 and exon 21 mutations treated with gefitinib and erlotinib. Cin Cancer Res 2006, I 2:839-44. 
23. Histopathological Typing of Lung and Pleural Tumors. In International Histological Classification of Tumors 3rd edition. World Health Organization. Geneva; 1999.

24. Therasse P, Arbuck SG, Eisenhauer EA, Wanders J, Kaplan RS, Rubinstein L, Verweij J, Van Glabbeke M, van Oosterom AT, Christian MC, Gwyther SG: New guidelines to evaluate the response to treatment in solid tumors. I Natl Cancer Inst 2000, 92:205-16.

25. Kurata T, Tamura K, Kaneda H, Nogami T, Uejima H, Asai G, Nakagawa K, Fukuoka M: Effect of re-treatment with gefitinib ('Iressa', ZD 1839) after acquisition of resistance. Ann Oncol 2004, I5:173-7.

26. Kobayashi S, Boggon TJ, Dayaram T, Janne PA, Kocher O, Meyerson M, Johnson BE, Eck MJ, Tenen DG, Halmos B: EGFR mutation and resistance of non-small-cell lung cancer to gefitinib. $N$ Engl J Med 2005, 352:786-92.

27. Pao W, Miller VA, Politi KA, Riely GJ, Somwar R, Zakowski MF, Kris MG, Varmus $\mathrm{H}$ : Acquired resistance of lung adenocarcinoma to gefitinib of erlotinib is associated with a second mutation in the EGFR kinase domain. Plos Med 2005, 2: I-II.

28. Pao W, Wang TY, Riely G], Miller VA, Pan Q, Ladanyi M, Zakowski MF, Heelan RT, Kris MG, Varmus HE: KRAS mutations and primary resistance of lung adenocarcinomas to gefitinib or erlotinib. Plos Med 2005, 2:57-6I.

29. Jain A, Tindell CA, Laux I, Hunter JB, Curran J, Galkin A, Afar DE, Aronson N, Shak S, Natale RB, Agus DB: Epithelial membrane protein-I is a biomarker of gefitinib resistance. Proc Natl Acad Sci USA 2005, 102: I 1858-63.

30. Omuro AMP, Kris MG, Miller VA, Franceschi E, Shah N, Milton DT, Abrey LE: High incidence of disease recurrence in the brain and leptomeninges in patients with nonsmall cell lung carcinoma after response to gefitinib. Cancer 2005, 103:2344-8.

3I. Cella D, Herbst RS, Lynch TJ, Prager D, Belani CP, Schiller JH, Heyes A, Ochs JS, Wolf MK, Kay AC, Kris MG, Natale RB: Clinically meaningful improvement in symptoms and quality of life for patients with non-small-cell lung cancer receiving gefitinib in a randomized controlled trial. J Clin Oncol 2005, 23:1-9.

32. Hotta K, Matsuo K, Ueoka H, Kiura K, Tabata M, Harita S, Gemba K, Yonei T, Bessho A, Tanimoto M: Continued gefitinib treatment after disease stabilization prolongs survival of Japanese patients with non-small-cell lung cancer: Okayama Lung Cancer Study Group experience. Ann Oncol 2005, 16:1817-23.

\section{Pre-publication history}

The pre-publication history for this paper can be accessed here:

http://www.biomedcentral.com/1471-2407/7/51/prepub

\section{Publish with Bio Med Central and every scientist can read your work free of charge}

"BioMed Central will be the most significant development for disseminating the results of biomedical research in our lifetime. "

Sir Paul Nurse, Cancer Research UK

Your research papers will be:

- available free of charge to the entire biomedical community

- peer reviewed and published immediately upon acceptance

- cited in PubMed and archived on PubMed Central

- yours - you keep the copyright
Biomedcentral 